Russian Academy of Sciences, Far Eastern Branch

Botanical Garden-Institute

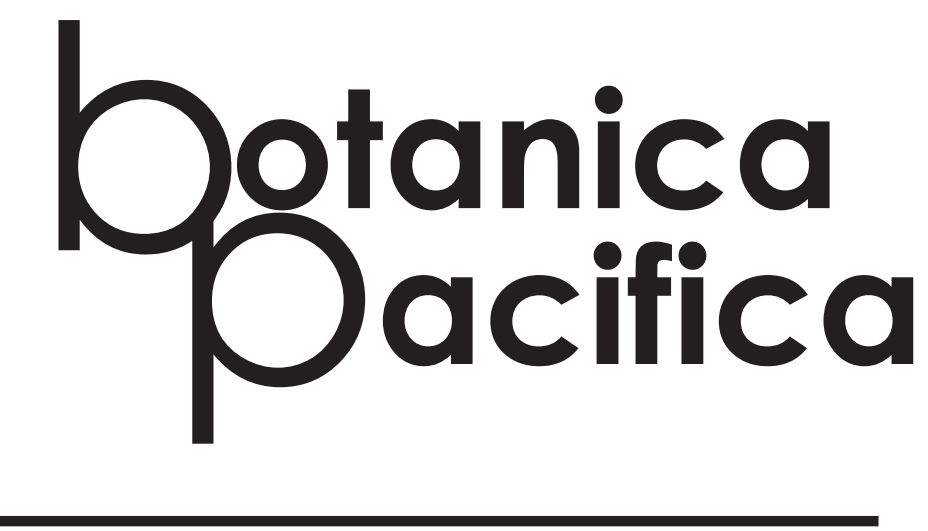

A JOURNAL OF PLANT SCIENCE
AND CONSERVATION

VOLUME 9, NO. 12020 


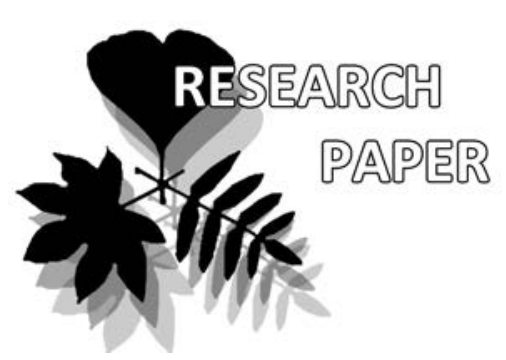

Viktor V. Sheiko

e-mail: viktorsheiko@mail.ru

${ }^{1}$ Sakhalin Branch of the

Botanical Garden-Institute FEB RAS, Yuzhno-Sakhalinsk, Russia

Manuscript received: 15.06 .2019

Review completed: 25.02 .2020

Accepted for publication: 03.04.2020

Published online: 05.04.2020

\section{Flower formation in different taxa of Lonicera L. Caprifoliaceae) in a culture in southern Sakhalin (Russia)}

\author{
Viktor V. Sheiko
}

\begin{abstract}
A B S T R A C T
The floral meristem of many orthotropic honeysuckles starts to form nearly a year before flowering. Such an early formation may serve to support the Nedoluzhko's hypothesis that honeysuckle phenorhythm types evolved from summer/fall to early summer, passing through the stages of late autumn, winter and early spring. The relationship between flowering dates and the dates when floral meristems begin to form is distinct from that of the subgenus Caprifolium and orthotropic honeysuckles. This difference allows us to deduce that there is a special evolutionary pathway for phenorhythm types in the Caprifolium subgenus: a shift from a summer/fall flowering period to an earlier - not later - period. The relationship between flowering dates and dates of floral meristem formation in species of the Tataricae series, related to the Lonicera section, is almost identical to that of the Rhodanthae subsection. This supplements previously established arguments that suggest Rhodanthae is the closest subsection to the Lonicera section.
\end{abstract}

K e y w o r d s : Lonicera, Caprifoliaceae, floral meristem, flowering periods

\section{P E 3 Ю M E}

Шейко В.В. Продолжительность формирования цветков в разных систематических группах рода Lonicera L. (Caprifoliaceae) в условиях культуры на юге острова Сахацин (Россия). Фцорацьная меристема у многих ортотропных жимолостей формируется почти за гоА Ао цветения. Столь раннее формирование может служить аргументом в пользу гипотезы Недолужко, что феноритмотип жимолостей эволюционировац от метнеосеннего к раннелетнему через такие этапы, как позднеосенний, зимний и ранневесенний. Зависимость между датами зацветания и датами формирования флоральной меристемы разная в подроде Caprifolium и у ортотропных жимолостей. Аанное различие позволяет предполагать в пределах полрода Caprifolium особый путь эволюции феноритмотипов: смещение от метнеосеннего цветения не к более позАним, а, наоборот, к более ранним срокам. Зависимость межАу Аатами зацветания и датами формирования фморальной меристемы у виАов серии Tataricae, относящейся к секции Lonicera, почти совпадает с аналогичной зависимостью Аля подсекции Rhodanthae из секции Isika. Это Аополняет ранее известные аргументы, позволяющие считать, что к секции Lonicera наиболее близка подсекция Rhodanthae.

КАючевые слова: Lonicera, Caprifoliaceae, флоральная меристема, сроки зацветания, микрофенология
Early-summer flowering is a characteristic feature of all species of the Lonicera section and many species of other sections (except for the Nintooa (Sweet) Maxim.) in the genus Lonicera. Nedoluzhko (1984) considered the early-summer flowering in the genus as evolutionary progressive trait that arose from summer-autumn flowering through the stages of winter and early spring flowering. One of the ways to test this hypothesis is a comparative study of the dynamics of the ontogenesis of flower primordia in different systematic groups. The calendar dates of laying the floral meristem and the duration of the development of flower primordia can serve as the simple criteria for determining the stages of ontogenesis. Differences in these indicators observed under identical conditions can be considered as a manifestation of specific characters inherent to the distant ancestors of these species. The comparison of the species of the Lonicera section with species of other sections according to these criteria is of particular interest, since there are a number of paradoxical combinations of archaic and progressive traits among the traits of this section.

The contradictions in the analysis of the morphology of species of the genus Lonicera are reflected in the molecular systematics of the genus based on the analysis of nuclear and chloroplast DNA.

The objective of this study was to obtain data on the laying time of the floral meristem and the duration of the development of flower primordia in different systematic groups of the genus Lonicera in the collection of living plants of the Botanical Garden-Institute FEB RAS. Comparison of these data for species of different systematic groups in the genus Lonicera will open the possibility of testing the Nedoluzhko's hypothesis. 


\section{MATERIAL AND METHODS}

Forty species from the genus Lonicera from the collection of the Sakhalin Branch of the Botanical GardenInstitute FEB RAS were used in this study, in which we examined two characteristics: (1) the flowering start date, which was noted in the course of routine phenological observations recorded during the 2000-2018 period; (2) the dates of floral meristem formation in the generative buds, which were determined with a binocular microscope in microphenological studies during periods of 2004-2006 and 2017-2018. We examined buds from various sections from shoots of different types. The formation was set as earliest date in a particular season. In certain instances, it was impossible to establish the earliest appearance of floral meristem. We were only able to record a later development stage of the flower bud. In these cases, we studied the length of time between the appearance of floral meristem and that particular development stage in other (delayed) flower buds. These buds were selected either from plants of the same species or from closely related species with a similar phenorhythm. After determining the length of this period, we calculated an estimated date for the appearance of floral meristem in the species of interest. The years of 2004 and 2018 both saw abnormally cool summers. Since our microphenological observations lasted only five seasons, and occurrence rate for abnormally cool summers in the southern part of Sakhalin Island is less than $40 \%$, the data for these years were not included in the calculation of means. The average delay in floral meristem formation during such years was about 10 days. Therefore, the dates for these years shifted by 10 days. Given that the flower development period were determined over several months in most cases, any errors resulting from this correction could not have significantly affected the findings.

\section{RES U LTS}

Table 1 presents the collected data on flowering start dates, floral meristem formation dates and the duration of the flower development period in 40 species and one hybrid of the Lonicera genus. The species in the table are grouped according to their systematic position (after Rehder 1903). Supraspecific taxa, including Lonicera xylosteum L., were treated as generic taxa. Other supraspecific subdivisions examined:

Subgenera: Caprifolium (Adans.) Dipp. 1889 according to G. Krüssmann (1977).

Sections: Isoxylosteum Rehd. 1903, Isika Rehd. 1903, Nintooa (Sweet) Maxim. 1903, according to A. Rehder (1903).

Subsections: Purpurascentes Rehd., Pileatae Rehd., Caeruleae Rehd. 1903, Vesicariae Kom. 1901, Distegiae Rehd., Alpigenae Rehd., Rhodanthae Rehd., Phenianthi (Rafin.) Rehd., Cypheolae Raf. according to A. Rehder (1903); Fragrantissimae Rehd. emend. Nedoluzh., Bracteatae Hook. f. et Thoms. 1858 emend. Nedoluzh. 1986 according to V.A. Nedoluzhko (1986).

Series: Praeflorentes (Nakai) Nedoluzh. 1984, Nigrae Pojark. ex Nedoluzh. 1984, Orientales Pojark. ex. Nedoluzh. 1984 Maximowiczianae Pojark. ex Nedoluzh. 1984, according to V.A. Nedoluzhko, (1984 a); Tataricae (Rehd.) Nedoluzh. 1983 Ruprechtianae Pojark. ex. Nedoluzh. 1983, Maackinae Pojark. ex Nedoluzh. 1983, according to V.A. Nedoluzhko, (1983) and the Hispidae Pojark series. (1958. descr. ross.), Asperifoliae Pojark. (1958. descr. ross.), Altmannianae Pojark. (1958. descr. ross.), Altmannianae Pojark. (1958. descr. ross.), Heterophyllae Pojark. (1958. descr. ross.) according to Poyarkova (1958).
In most orthotropic honeysuckles, the floral meristems form 1-1.5 months after flowering begins. It may occur, although infrequently, two weeks earlier or later. For climbing honeysuckle, the situation is slightly different in that floral meristem starts forming at a minimum of more than two months after flowering begins. Most often, it occurs around four months after flowering, i.e. toward the end of autumn and sometimes even in spring of the following year. The latest recorded floral meristem formation was found in climbing Lonicera benryi from the Nintooa section. Therefore, different systematic groups of honeysuckle displayed different ranges in flowering periods (hereafter referred to as RFS) and in the lengths of the flowers' development periods (hereafter, RDFD). RFS in the Caprifolium subgenus is relatively small and significantly inferior its considerably more variable RDFD (Fig. 1). The Lonicera subgenus has a wider RFS and RDFD than Caprifolium. However, this difference in RDFD is due solely to the species from the Nintooa section. If we exclude this section from the Lonicera subgenus analysis, i.e. evaluate only orthotropic honeysuckles, then we find the opposite, where the RDFD is inferior to the RFS.

When comparing the same values in lower-ranking taxa, we see that the RFS within the Caprifolium subgenus is generally the same in the Cypheolae and Caprifolium subsections. Meanwhile, the RDFD is significantly higher in the Caprifolium subsection than in Cypheolae (Fig. 1). The RDFD exceeds the RFS in both subsections. The situation is different for orthotropic honeysuckle of the Lonicera subgenus. Within the Isike a section, the genus's largest, both values are higher than in Lonicera. However, the RFS in the Isika section is larger than the RDFD, while this relationship is inversed in Lonicera (Fig. 1).

The relationship of these values for various subsections within the Isika section shows that the RDFD does not exceed the RFS. It also does not exceed the RFS for those series in the Lonicera section for which there is sufficient RDFD data (Fig. 1). A large RDFD for a section generally ensures variation among the series (for some of which there is insufficient RDFD data).

If we graphically represent the relationship between the length of the flower development period and the flowering dates for each of the 40 species (Fig. 2), then a large number of points for certain supraspecific taxa fall outside the main array. This is especially true for the subgenus Caprifolium and among the section Nintooa in the subgenus Lonicera.

Analyzing the relationship between flowering dates and the dates of floral meristem formation in those supraspecific taxa for which there is sufficient data yields the graph shown in Figure 3. Clearly, this relationship in the subgenus Caprifolium differs than that in the variety of subsections and series of this genus's orthotropic members.

An attempt to link flowering dates with the development stage observed in the plants at the beginning of winter did not reveal any connection with the species' systematic position.

\section{DISCUSSION}

Nedoluzhko (1984 b) considered the summer/autumn phenorhythm inherent in all species of the Nintooa section to be the primary flowering phenorhythm for the Lonicera 
Table 1. Dates of flowering, formation of floral meristem and duration of the development of flowers

\begin{tabular}{|c|c|c|c|c|c|c|}
\hline Section & Subsection & Series & Species & $\begin{array}{l}\text { Date of } \\
\text { flowering } \\
\text { start }\end{array}$ & $\begin{array}{l}\text { Date of floral } \\
\text { meristem } \\
\text { formation }\end{array}$ & $\begin{array}{l}\text { Duration } \\
\text { of flower } \\
\text { development } \\
\text { (days) }\end{array}$ \\
\hline \multicolumn{7}{|c|}{ Subgenus Lonicera } \\
\hline Isoxylosteum & & & Lonicera mirtillus Hook. f. et Thoms. & 5.06 & $12.07 *$ & 327 \\
\hline \multirow[t]{22}{*}{ Isika } & \multirow[t]{4}{*}{ Purpurascentes } & & L. utahensis Wats. & 15.05 & 16.06 & 331 \\
\hline & & & L. canadensis Marsh. & 16.05 & $16.06^{* *}$ & 332 \\
\hline & & & L. gracilipes Miq. var. glandulosa Maxim. & 29.05 & $6.07 *$ & 324 \\
\hline & & & L. tangutica Maxim. & 20.07 & 6.08 & 346 \\
\hline & Caeruleae & & L. caerulea $\mathrm{L}$. & 18.05 & 16.06 & 334 \\
\hline & Pileatae & & L. pileata Oliv. & 27.06 & $21.08^{*}$ & 308 \\
\hline & Vesicariae & & L. vesicaria Kom. & 25.06 & 10.08 & 317 \\
\hline & \multirow{2}{*}{$\begin{array}{l}\text { Fragrantissimae } \\
\text { s.l. }\end{array}$} & Praeflorentes & L. praeflorens Batal. & 3.05 & $8.06^{* *}$ & 327 \\
\hline & & Altmannianae & L. altmannii Regel. et Schmalh. & 20.05 & 16.06 & 336 \\
\hline & \multirow{2}{*}{$\begin{array}{l}\text { Bracteatae s. } \\
\text { str. }\end{array}$} & Hispidae & L. hispida Pall. ex Roem. et Schult. & 30.05 & 16.06 & 346 \\
\hline & & Asperifoliae & L. olgae Regel. et Schmalh. & 3.06 & $16.06^{*}$ & 350 \\
\hline & \multirow[t]{2}{*}{ Distegiae } & & L. tolmatchevii Pojark. & 15.05 & $15.06^{*}$ & 322 \\
\hline & & & L. involucrata Banks ex Spreng. & 23.05 & 28.06 & 327 \\
\hline & \multirow{3}{*}{ Alpigenae } & Alpigenae & L. glehnii Fr. Schmidt & 25.05 & $25.06^{*}$ & 332 \\
\hline & & & L. alpigena $\mathrm{L}$. & 2.06 & 1.07 & 332 \\
\hline & & Heterophyllae & L. webbiana Wall. & 28.05 & $1.07 *$ & 328 \\
\hline & \multirow[t]{6}{*}{ Rhodanthae } & Nigrae & L. chamissoi Bunge & 3.06 & $10.07 * *$ & 326 \\
\hline & & & L. nigra $\mathrm{L}$. & 7.06 & $20.07 *$ & 320 \\
\hline & & Orientales & L. caucasica Pall. & 23.06 & $15.08^{*}$ & 310 \\
\hline & & & L. discolor Lindl. & 26.06 & 10.08 & 318 \\
\hline & & Maximowiczianae & L. sachalinensis Fr. Schmidt & 16.06 & 1.08 & 318 \\
\hline & & & L. maximowiczii Regel & 16.06 & $1.08^{*}$ & 318 \\
\hline \multirow[t]{10}{*}{ Lonicera } & & Lonicera & L. xylosteum L. f. mollis Regel & 5.06 & 5.07 & 332 \\
\hline & & & L. chrysantha Turcz. ex Ledeb. & 14.06 & $12.07 * *$ & 335 \\
\hline & & Ruprechtianae & L. morrowii A. Gray & 17.06 & 6.08 & 313 \\
\hline & & & L. ruprechtiana Regel & 14.06 & $5.08 * *$ & 311 \\
\hline & & Tataricae & L. karataviensis Pavl. & 7.06 & 16.07 & 324 \\
\hline & & & L. tatarica $\mathrm{L}$. & 18.06 & $7.08 * *$ & 313 \\
\hline & & & L. floribunda Boiss. et Buhse & 22.06 & $15.08^{*}$ & 309 \\
\hline & & Maackinae & L. prostrata Rehd. & 10.06 & $15.08^{*}$ & 297 \\
\hline & & & L. maackii Herd. & 22.06 & 15.08 & 309 \\
\hline & & hybrid & L. quinquelocularis Hardw. $\times$ L. maackii & 25.06 & $7.09 *$ & 289 \\
\hline Nintooa & & & L. benryi Hemsl. & 28.07 & 10.05 & 79 \\
\hline \multicolumn{7}{|c|}{ Subgenus Caprifolium } \\
\hline & \multirow{5}{*}{$\begin{array}{l}\text { Phenianthi } \\
\text { Cypheolae }\end{array}$} & & L. sempervirens $\mathrm{L}$. & 15.07 & 9.04 & 97 \\
\hline & & & L. dioica $\mathrm{L}$. & 17.06 & 31.08 & 288 \\
\hline & & & L. dioica $\times$ birsuta & 6.07 & $27.10^{*}$ & 250 \\
\hline & & & L. prolifera Rehd. & 7.07 & $5.11 *$ & 242 \\
\hline & & & L. birsuta Eaton & 13.07 & $5.11 *$ & 248 \\
\hline & \multirow{2}{*}{\multicolumn{2}{|c|}{ Caprifolium }} & L. caprifolium L. & 25.06 & $28.08^{*}$ & 299 \\
\hline & & & L. periclymenum L. & 22.07 & 26.04 & 87 \\
\hline
\end{tabular}

Notes: ${ }^{*}$ - adjustment in connection with the omission of the date of formation of the floral meristem; ${ }^{* *}-$ adjustment due to cold summer

genus. While some species in this sections are common in the tropics, most are found in the subtropics. It is the opinion of this author that honeysuckle in the tropical climates of previous geological ages initially flowered during the late summer and in autumn. This autumnal flowering was replaced by a late autumnal one as a result of the differentiation by altitudinal belts in vegetation during orogenic processes, with a likely winter flowering period acting as an intermediate stage. Further climatic cooling led to dormancy in winter and early springtime flowering. In modern honeysuckles, winter flowering is typically found in the Eastern Chinese Lonicera fragrantissima Lindl. et Paxt. (Yang et al. 2011). It is perhaps the most archaic member of its evolutionary branch, which includes an eponymous subsection and the Bracteatae subsection. The winter phenorhythm eventually transformed into a late spring period 


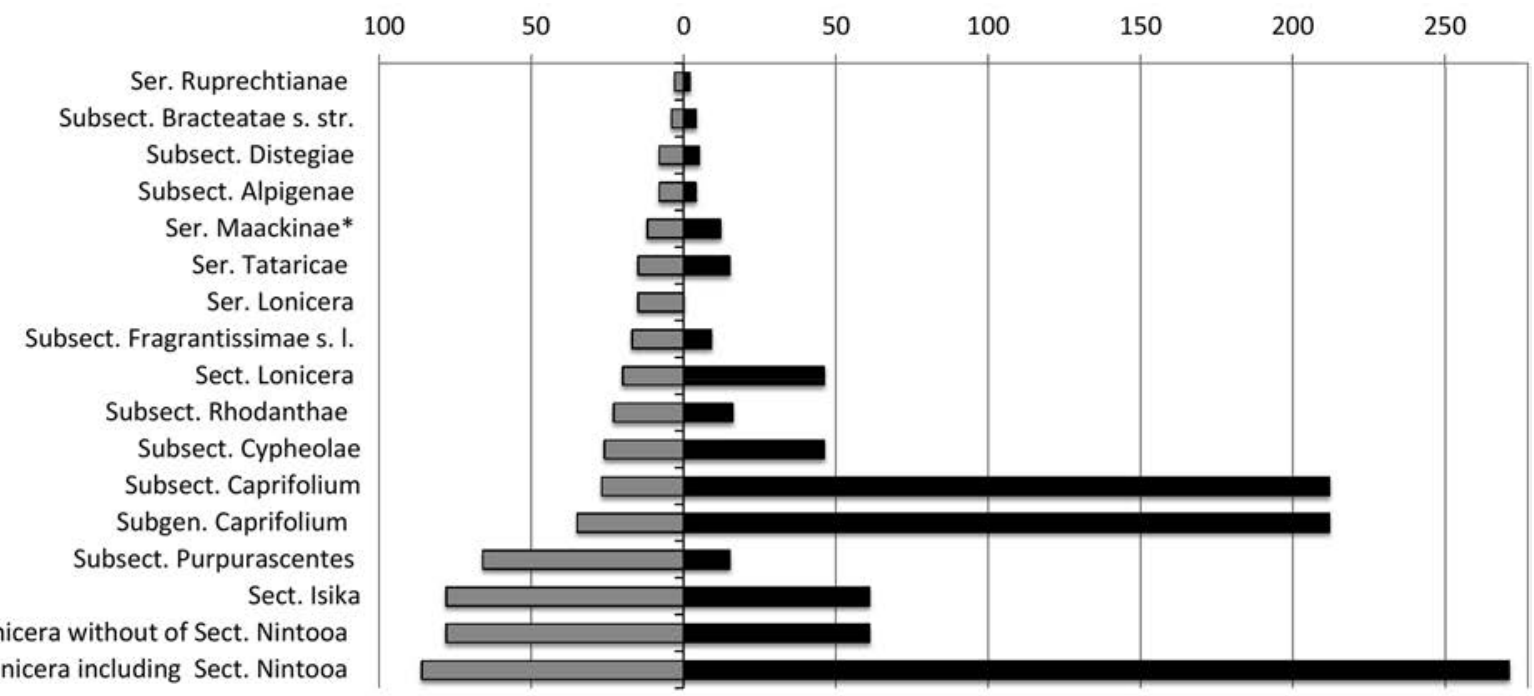

Subgen. Lonicera without of Sect. Nintooa
Subgen. Lonicera including Sect. Nintooa

Figure 1 Ranges of flowering start dates (from earliest to latest for a systematic group) (left of zero axis) and of the duration of flower development (right of zero axis) in different systematic groups of the genus Lonicera $\mathrm{L}$.

and, later still, early summer. Nedoluzhko did not distinguish between orthotropic shrubbery and climbing honeysuckle in his analyses on the phenorhythm shift in the Lonicera genus. The formation of the floral meristem almost a year before flowering can be considered as preserving the ontogeny of the traits inherent in the ancestors of these Lonicera species. A completely different relationship in Caprifolium between the flowering dates and floral meristem

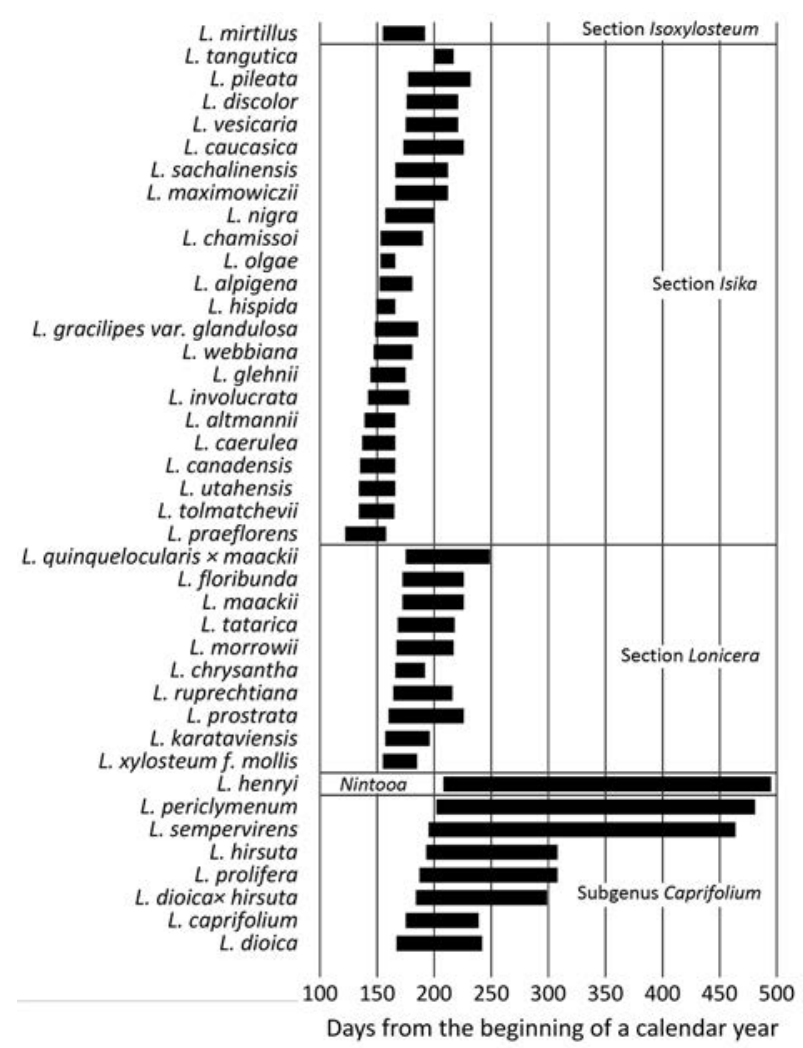

Figure 2 The time period of formation of floral meristem in different subgenera of the genus Lonicera $\mathrm{L}$. formation dates suggests a different evolutionary pathway for the phenorhythms in this subgenus. Moreover, there are no species in this subgenus with winter or early springtime flowering. This subgenus likely experienced a shift from a summer/ fall flowering period to an earlier-not later-period.

Figure 3 shows the relationships between flowering dates and dates of floral meristem formation in Lonicera species. The species from the Tataricae series (L. floribunda,

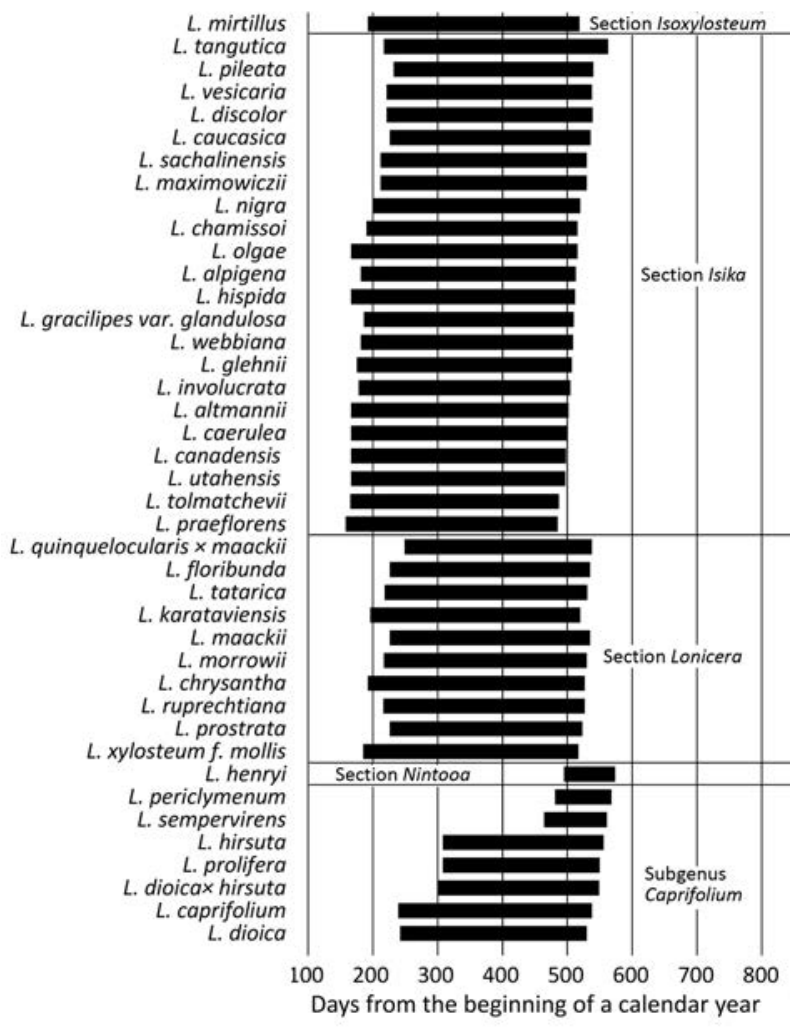

Figure 3 The time period from the beginning of flowering to the beginning of formation of floral meristem in different subgenera of the genus Lonicera L. 
L. tatarica, L. karataviensis) have nearly the same dates of meristem formation as species of the Rhodanthae subsection. In this case, the correspondence can be viewed as additional confirmation of the Lonicera section's proximity to the Rhodanthae subsection (part of the Isika section), as evidenced by chloroplast DNA sequencing (Theis et al. 2008, Nakaji et al. 2015). Theis et al. (2008) reported a conflicting findings from the chloroplast DNA and nuclear DNA analyses, regarding the Lonicera section. Some inconsistencies in opinions on the phylogenetic relationships may arise when analyzing the morphological features of this section's species and the fact that there is no polyploidy (unlike in other sections). Primitive characteristics also appear in large shrubbery (the largest for orthotropic honeysuckle), immature buds, and evanescent pith (characteristic in relatives of the Symphoricarpos Duham. и Leycesteria Wall. genera). The origin of the this section could possibly be the result of introgression, but the morphological similarity, chloroplast DNA findings and the data from our microphenological studies suggests that the greatest contribution to this section's formation came from the Rhodanthae subsection. For further investigation into this matter, it will be necessary to conduct chloroplast DNA testing on a larger species sampling from both the Lonicera section and the Rhodanthae subsection. Most likely, analysis of relatively ancient species in the Lonicera section, such as Lonicera quinquelocularis Hardw., L. arborea Boiss., L. floribunda, and L. brevisepala Hsu et H.J. Wang (a widespread species to the west of the main habitats of the Ruprechtianae series), will be of particular interest. It would also be prudent to study the floral meristem formation periods in most of these species.

\section{CONCLUSIONS}

Research has found that the floral meristem of many orthotropic honeysuckles forms nearly a year before flowering, a feature that can be viewed as preserving the ontogeny of the character inherent in the distant ancestors of these Lonicera species. In turn, this may serve to support Nedoluzhko's hypothesis that honeysuckle phenorhythm types evolved from summer/fall to early summer, passing through the stages of late autumn, winter and early spring.

The relationship between flowering dates and the dates when floral meristems begin to form is distinct from that of the subgenus Caprifolium and orthotropic honeysuckles (species of the Lonicera subgenus, minus the Nintooa section). This difference allows us to deduce that there is a special evolutionary pathway for phenorhythm types in the Caprifolium subgenus. It is likely that this subgenus experienced a shift from a summer/fall flowering period to an earlier-not later-period.

The relationship between flowering dates and dates of floral meristem formation in species of the Tataricae series, from the Lonicera section, is almost identical to that of the Rhodanthae subsection. This supplements previously established arguments, based on morphological similarity and chloroplast DNA analysis that suggest Rhodanthae is the closest subsection to the Lonicera section.

\section{ACKNOWLEDGEMENTS}

The work was supported by the Ministry of Science and Higher Education of Russia (special program on support of biocollections to BGI FEB RAS).

\section{LITERATURE CITED}

Krüssmann, G. 1977. Handbuch der Laubgehölze. Band 2. Aufl. Verlag Paul Parey, Berlin, Hamburg, 468 p.

Nakaji, M., N. Tanaka, T. Sugawara 2015. A molecular phylogenetic study of Lonicera L. (Caprifoliaceae) in Japan based on chloroplast DNA sequences. Acta Phytotaxonomica et Geobotanica 66 (3): 137-151.

Nedoluzhko, V.A. 1983. New system of section Lonicera of the genus Lonicera (Caprifoliaceae). Novosti sistematiki vysshikh rastenii 20:176-179 (in Russian with English summary). [Недолужко В.А. 1983. Новая система секции Lonicera рода Lonicera (Caprifoliaceae) // Новости систематики высших растений. Т. 20. С. 176-179].

Nedoluzhko, V.A. 1984a. Summary of species of the genus Lonicera (Caprifoliaceae) of the Soviet Far East. Botanicheskii Zhurnal 69 (3): 366-370 (in Russian with English summary). [Недолужко В.А. 1984а. Конспект видов рода Lonicera (Caprifoliaceae) советского Аальнего Востока // Ботанический журнал. Т. 69, № 3. С. 366-370].

Nedoluzhko, V.A. 1984b. Phenorhythms of honeysuckle in connection with its morphological evolution. In: Phenological phenomena in Primorye (A.N. Prilutskiy, ed.), pp. 24-30, DVNTs RAN, Vladivostok (in Russian). [НеАолужко B.A. 1984 b. Феноритмы рода жимолость в связи с его морфологической эволюцией // Фенологические явления в Приморье / поА реА. А.В. Прилуцкого. ВАаАивосток: АВНЦ АН СССР. С. 24-30].

Nedoluzhko, V.A. 1986. A systematic and geographical review of honeysuckles of the northeast of Eurasia. Komarovskiye chteniya 33: 54-109 (in Russian with English summary). [Недолужко B.A. 1986. Систематический и географический обзор жимолостей северо-востока Евразии // Комаровские чтения Вып. 33. С. 54-109].

Poyarkova, A.I. 1958. Honeysuckle family - Caprifoliaceae Vent. In: Flora of the USSR (B.K. Shishkin, ed.), pp. 419584, Izdatelstvo Akademii nauk SSSR, Moscow; Leningrad (in Russian). [Пояркова А.И. 1958. Сем. Жимомостные - Caprifoliaceae Vent. // ФАора СССР / поА ред. Б.К. Шишкина. Москва; Аенинград: ИзА-во АН CCCP, T. 23. C. 419-584].

Qiner, Y., S. Landrein, J. Osborne, \& R. Borosova 2011. Caprifoliaceae. In: Flora of China, vol. 19 (Wu, Z.Y., P.H. Raven \& D.Y. Hong, eds), pp. 616-641, Science Press, Beijing, and Missouri Botanical Garden Press, St. Louis. Available from: http://www.efloras.org/florataxon.aspx?flora_ id=2\&taxon_id=10159/ Last accessed 28.02.2011.

Rehder, A. 1903. Synopsis of the genus Lonicera. Annual Report of the Missouri Botanical Garden 14: 27-232.

Theis, N., J. M. Donoghue, \& J. Li 2008. Phylogenetics of the Caprifolieae and Lonicera (Dipsacales) based on nuclear and chloroplast DNA sequences. Systematic Botany 33: 776-783]. 